\title{
Yonghaparkia alkaliphila gen. nov., sp. nov., a novel member of the family Microbacteriaceae isolated from an alkaline soil
}

Correspondence

Jung-Hoon Yoon

jhyoon@kribb.re.kr

\author{
Jung-Hoon Yoon, ${ }^{1}$ So-Jung Kang, ${ }^{1}$ Peter Schumann ${ }^{2}$ and Tae-Kwang Oh ${ }^{1}$ \\ ${ }^{1}$ Korea Research Institute of Bioscience and Biotechnology (KRIBB), PO Box 115, Yusong, \\ Taejon, Korea \\ ${ }^{2}$ DSMZ - Deutsche Sammlung von Mikroorganismen und Zellkulturen GmbH, Mascheroder \\ Weg 1b, D-38124 Braunschweig, Germany
}

Two Gram-positive, non-motile, non-spore-forming and rod-shaped actinomycete strains, KSL$113^{\top}$ and KSL-133, were isolated from an alkaline soil in Korea, and their taxonomic positions were investigated by using a polyphasic approach. The strains grew optimally at $30^{\circ} \mathrm{C}$ and $\mathrm{pH} 9 \cdot 0$. Phenotypic, phylogenetic and genetic similarities indicated that strains $\mathrm{KSL}-113^{\top}$ and $\mathrm{KSL}-133$ represent the same species. Phylogenetic analyses based on $16 \mathrm{~S}$ rRNA gene sequences showed that strains KSL-113 ${ }^{\top}$ and KSL-133 fell within the family Microbacteriaceae of the suborder Micrococcineae, the highest $16 \mathrm{~S}$ rRNA gene sequence similarity values (98.2\%) being obtained with respect to Microcella putealis CV-2 ${ }^{\top}$. The $16 \mathrm{~S}$ rRNA gene sequence similarities between strains KSL-113 ${ }^{\top}$ and KSL-133 and the other members of the family Microbacteriaceae used in the phylogenetic analysis were less than $96 \cdot 0 \%$. Strains KSL-113 ${ }^{\top}$ and KSL-133 could be clearly distinguished from members of the family Microbacteriaceae on the basis of differences in chemotaxonomic properties, including the predominant menaquinone type, the cell-wall peptidoglycan type and the fatty acid profile. Accordingly, on the basis of the combined phenotypic, chemotaxonomic and phylogenetic data, strains KSL-113 ${ }^{\top}$ and KSL-133 constitute a novel genus and species of the family Microbacteriaceae, for which the name Yonghaparkia alkaliphila gen. nov., sp. nov. is proposed. The type strain of Yonghaparkia alkaliphila is KSL-113 ${ }^{\top}(=\mathrm{KCTC}$ $19126^{\top}=$ CIP $108920^{\top}$ ).
The family Microbacteriaceae was proposed by Park et al. (1993) to accommodate the Gram-positive actinomycete genera Agromyces, Aureobacterium, Clavibacter, Curtobacterium and Microbacterium, all of which contain peptidoglycan of type B. Stackebrandt et al. (1997) assigned two more genera, Rathayibacter (Zgurskaya et al., 1993) and Agrococcus (Groth et al., 1996), to the family Microbacteriaceae. Subsequently, 14 more genera - Leucobacter (Takeuchi et al., 1996), Cryobacterium (Suzuki et al., 1997), Frigoribacterium (Kämpfer et al., 2000), Leifsonia (Evtushenko et al., 2000), Subtercola (Männistö et al., 2000), Mycetocola (Tsukamoto et al., 2001), Agreia (Evtushenko et al., 2001), Okibacterium (Evtushenko et al., 2002), Plantibacter (Behrendt et al., 2002), Rhodoglobus (Sheridan et al., 2003), Salinibacterium (Han et al., 2003), Gulosibacter

Abbreviation: DAB, 2,4-diaminobutyric acid.

The GenBank/EMBL/DDBJ accession numbers for the 16S rRNA gene sequences of strains $\mathrm{KSL}-113^{\top}$ and $\mathrm{KSL}-133$ are DO256087 and DQ256088, respectively.

The cellular fatty acid compositions of strains KSL-113 ${ }^{\top}$ and KSL-133 are presented in a supplementary table available in IJSEM Online. and Pseudoclavibacter (Manaia et al., 2004) and Microcella (Tiago et al., 2005) - have been assigned to the family, and the genera Microbacterium and Aureobacterium were unified (Takeuchi \& Hatano, 1998). The genus Zimmermannella was proposed by Lin et al. (2004) as a member of the family Microbacteriaceae, but the type species of the genus Zimmermannella helvola is a later homotypic synonym of Pseudoclavibacter helvolus and the genus Zimmermannella is therefore illegitimate. In this study, we describe two Grampositive and alkaliphilic bacterial strains, KSL-113 ${ }^{\mathrm{T}}$ and KSL-133, which were found to be most closely related phylogenetically to the family Microbacteriaceae on the basis of 16S rRNA gene sequence comparisons. To our knowledge, no alkaliphilic micro-organism has been assigned to the family Microbacteriaceae. Accordingly, the aim of the present study was to determine the exact taxonomic positions of strains KSL- $113^{\mathrm{T}}$ and KSL-133 by using a polyphasic approach.

An alkaline soil sample collected from Kwangchun, Korea, was used as the source for the isolation of bacterial strains. Strains KSL-113 ${ }^{\mathrm{T}}$ and KSL-133 were isolated by means of the standard dilution plating technique, at $30{ }^{\circ} \mathrm{C}$ on 
$10 \times$ diluted nutrient agar (NA; Difco) with the $\mathrm{pH}$ adjusted to $10 \cdot 0$. The morphological, physiological and biochemical characteristics of strains KSL-113 ${ }^{\mathrm{T}}$ and KSL-133 were investigated using routine cultivation at $30^{\circ} \mathrm{C}$ on $2 \times$ diluted NA with the $\mathrm{pH}$ adjusted to $9 \cdot 0$. Cell morphology was examined by using light microscopy (E600; Nikon) and transmission electron microscopy. Flagellation was determined by using a Philips CM-20 transmission electron microscope with cells from exponentially growing cultures: for this purpose, the cells were negatively stained with $1 \%$ $(\mathrm{w} / \mathrm{v})$ phosphotungstic acid and the grids were examined after being air-dried. The Gram reaction was determined by using the bioMérieux Gram stain kit according to the manufacturer's instructions. Growth at various tempera-

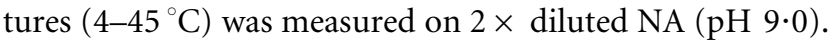
Growth in the absence of $\mathrm{NaCl}$ and at various $\mathrm{NaCl}$ concentrations $(0.5$ and $1 \cdot 0-5.0 \%, w / v$, at intervals of $1.0 \%)$ was investigated in $2 \times$ diluted trypticase soy broth prepared according to the formula of the Difco medium except that no $\mathrm{NaCl}$ was used. The $\mathrm{pH}$ range for growth was determined in $2 \times$ diluted nutrient broth (Difco) adjusted, prior to sterilization, to various $\mathrm{pH}$ values $(\mathrm{pH} 4 \cdot 5-10 \cdot 5$, at intervals of $0.5 \mathrm{pH}$ units) by the addition of $\mathrm{HCl}$ or $\mathrm{Na}_{2} \mathrm{CO}_{3}$. Growth under anaerobic conditions was determined after incubation in an anaerobic chamber on $2 \times$ diluted NA $(\mathrm{pH} \mathrm{9.0)}$ and on $2 \times$ diluted NA ( $\mathrm{pH} \mathrm{9.0)} \mathrm{supplemented}$ with nitrate, both of which had been prepared anaerobically using nitrogen. Catalase and oxidase activities and the hydrolysis of casein, gelatin, hypoxanthine, starch, Tweens 20, 40, 60 and 80, tyrosine, urea and xanthine were determined as described by Cowan \& Steel (1965), but with the modification that the $\mathrm{pH}$ of the media was adjusted to $9 \cdot 0$. Aesculin hydrolysis and nitrate reduction were studied as described previously (Lanyi, 1987), with the modification that the $\mathrm{pH}$ of the media was adjusted to $9 \cdot 0$. The utilization of substrates as sole carbon and energy sources was tested according to the method of Kämpfer et al. (1991), with the modification that the $\mathrm{pH}$ of the media was adjusted to $9 \cdot 0$. Antibiotic sensitivity was tested on plates with $2 \times$ diluted NA ( $\mathrm{pH} 9 \cdot 0)$ and antibiotic discs containing the following antibiotics: polymyxin B $(100 \mathrm{U})$, streptomycin $(50 \mu \mathrm{g})$, penicillin $\mathrm{G}(20 \mathrm{U})$, chloramphenicol $(100 \mu \mathrm{g})$, ampicillin $(10 \mu \mathrm{g})$, cephalothin $(30 \mu \mathrm{g})$, gentamicin $(30 \mu \mathrm{g})$, novobiocin $(5 \mu \mathrm{g})$, tetracycline $(30 \mu \mathrm{g})$, kanamycin $(30 \mu \mathrm{g})$, lincomycin $(15 \mu \mathrm{g})$, oleandomycin $(15 \mu \mathrm{g})$, neomycin $(30 \mu \mathrm{g})$ and carbenicillin $(100 \mu \mathrm{g})$. Enzyme activity was tested by using the API ZYM system (bioMérieux); the cell suspension used to inoculate the system was prepared using

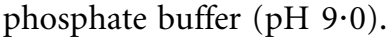

Cell biomass for DNA extraction and for analyses of the cell wall, isoprenoid quinones and polar lipids was obtained from cultures grown in $2 \times$ diluted nutrient broth at $30^{\circ} \mathrm{C}$. Chromosomal DNA was isolated and purified according to the method described previously (Yoon et al., 1996), with the exception that RNase T1 was used in combination with RNase A to minimize contamination with RNA. The 16S rRNA gene sequence was amplified by using a PCR with two universal primers as described previously (Yoon et al., 1998). Sequencing of the amplified 16S rRNA gene and phylogenetic analysis were performed as described by Yoon et al. (2004). The DNA G+C content was determined according to the method of Tamaoka \& Komagata (1984), with the modification that the DNA was hydrolysed and the resultant nucleotides were analysed by reversed-phase HPLC. The presence or absence of diaminopimelic acid in the peptidoglycan was determined according to the method described by Komagata \& Suzuki (1987). Preparation of the cell walls and determination of the peptidoglycan structure were carried out by using modified methods of Schleifer \& Kandler (1972) and MacKenzie (1987). Isoprenoid quinones were extracted according to the method of Komagata \& Suzuki (1987) and analysed using reversed-phase HPLC and a YMC ODS-A $(250 \times 4.6 \mathrm{~mm})$ column. Polar lipids were extracted according to the procedures described by Minnikin et al. (1984) and were identified by twodimensional TLC followed by spraying with the appropriate detection reagents (Minnikin et al., 1984; Komagata \& Suzuki, 1987). For analysis of fatty acid methyl esters, cell mass of strains KSL-113 ${ }^{\mathrm{T}}$ and KSL-133 was harvested from plates with $2 \times$ diluted NA ( $\mathrm{pH} 9 \cdot 0$ ) after incubation for 10 days at $30{ }^{\circ} \mathrm{C}$. Fatty acid methyl esters were extracted and prepared according to the standard protocol of the MIDI/ Hewlett Packard Microbial Identification System (Sasser, 1990).

The cells of strains KSL- $113^{\mathrm{T}}$ and KSL-133 were Grampositive and non-spore-forming short rods or rods. Strains KSL- $113^{\mathrm{T}}$ and KSL-133 showed optimal growth at $\mathrm{pH} 9 \cdot 0$; growth occurred at $\mathrm{pH} 7 \cdot 5$, but not at $\mathrm{pH} 7 \cdot 0$. The two strains were identical in all of the morphological, cultural, physiological and biochemical characteristics tested in this study, except with regard to the utilization of some substrates. The phenotypic properties of strains KSL-113 and KSL-133 are given in the genus and species descriptions (see below) or are shown in Table 1. The almost-complete $16 \mathrm{~S}$ rRNA gene sequences of strains KSL- $113^{\mathrm{T}}$ and KSL-133 were identical and comprised $1476 \mathrm{nt}$, representing approximately $96 \%$ of the Escherichia coli $16 \mathrm{~S}$ rRNA gene sequence. Comparative 16S rRNA gene sequence analyses revealed that strains KSL-113 ${ }^{\mathrm{T}}$ and KSL-133 were phylogenetically most closely affiliated to the family Microbacteriaceae of the suborder Micrococcineae, particularly with respect to Microcella putealis $\mathrm{CV}-2^{\mathrm{T}}$ and Frigoribacterium faeni DSM $10309^{\mathrm{T}}$ (Fig. 1). In the neighbour-joining tree based on $16 \mathrm{~S}$ rRNA gene sequences, strains KSL-113 ${ }^{\mathrm{T}}$ and KSL-133 joined the phylogenetic lineage of Microcella putealis $\mathrm{CV}-2^{\mathrm{T}}$ at a bootstrap resampling value of $100 \%$ (Fig. 1). The relationship between strains KSL-113 ${ }^{\mathrm{T}}$ and KSL-133 and Microcella putealis $\mathrm{CV}-2^{\mathrm{T}}$ was maintained in trees generated with the maximum-likelihood and maximum-parsimony algorithms (Fig. 1). The similarity values between the 16S rRNA gene sequences of strains KSL-113 ${ }^{\mathrm{T}}$ and KSL-133 and those of Microcella putealis $\mathrm{CV}-2^{\mathrm{T}}$ and Frigoribacterium faeni DSM $10309^{\mathrm{T}}$ were $98 \cdot 2$ and $96 \cdot 7 \%$, respectively. Strains KSL- $113^{\mathrm{T}}$ 
Table 1. Differential phenotypic characteristics of strains $\mathrm{KSL}-113^{\top}$ and $\mathrm{KSL}-133$ (Yonghaparkia gen. nov.) and the genera Microcella, Frigoribacterium and Mycetocola

Data for reference genera were taken from Tiago et al. (2005) (Microcella), Kämpfer et al. (2000) (Frigoribacterium) and Tsukamoto et al. (2001) (Mycetocola). +, Positive; -, negative; V, variable (results for the type strain of the type species in parentheses); ND, no data available. All taxa are positive for the Gram stain and catalase activity.

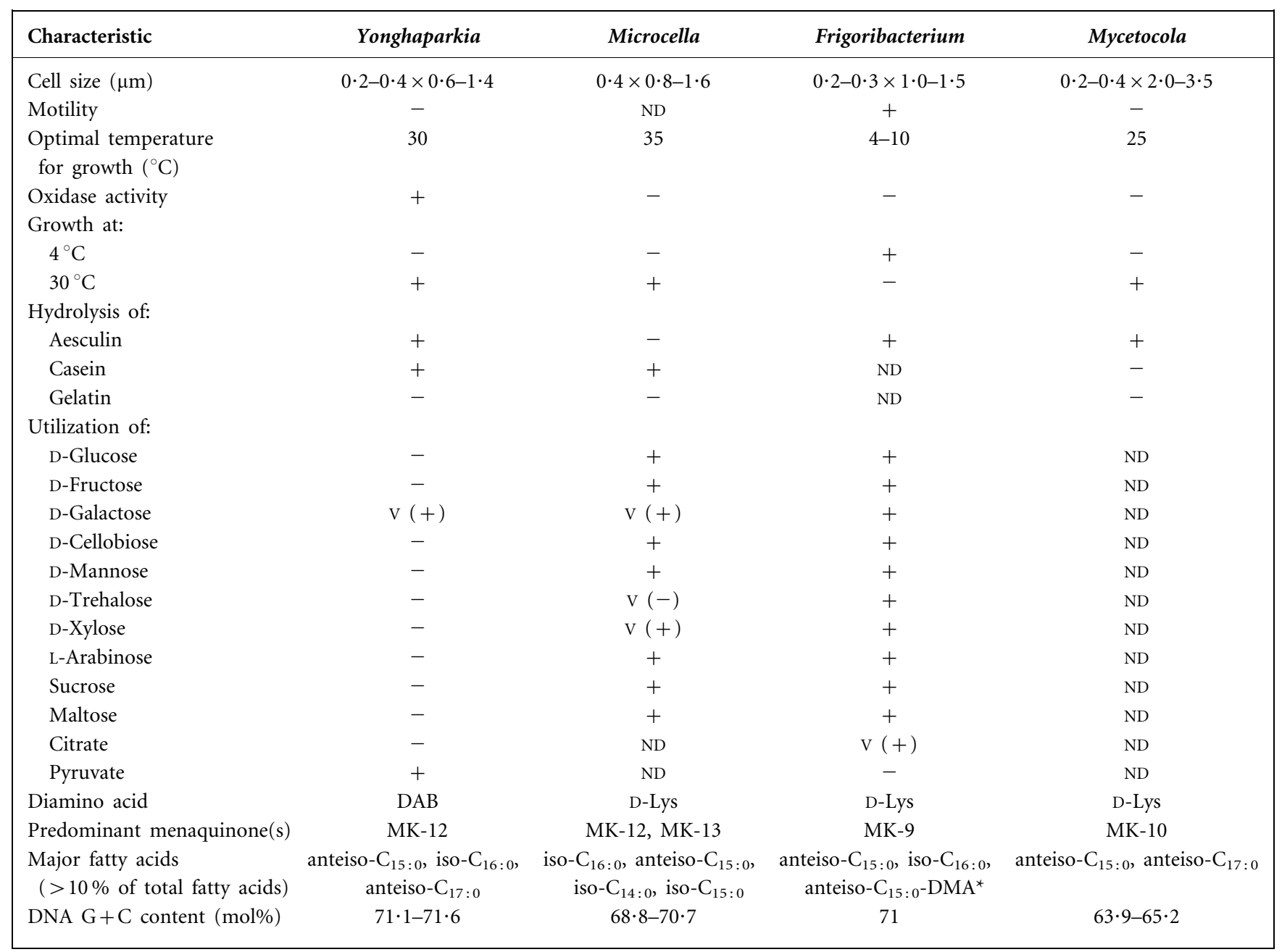

*anteiso- $\mathrm{C}_{15: 0}$-DMA, 1,1-Dimethyl-anteiso-pentadecane.

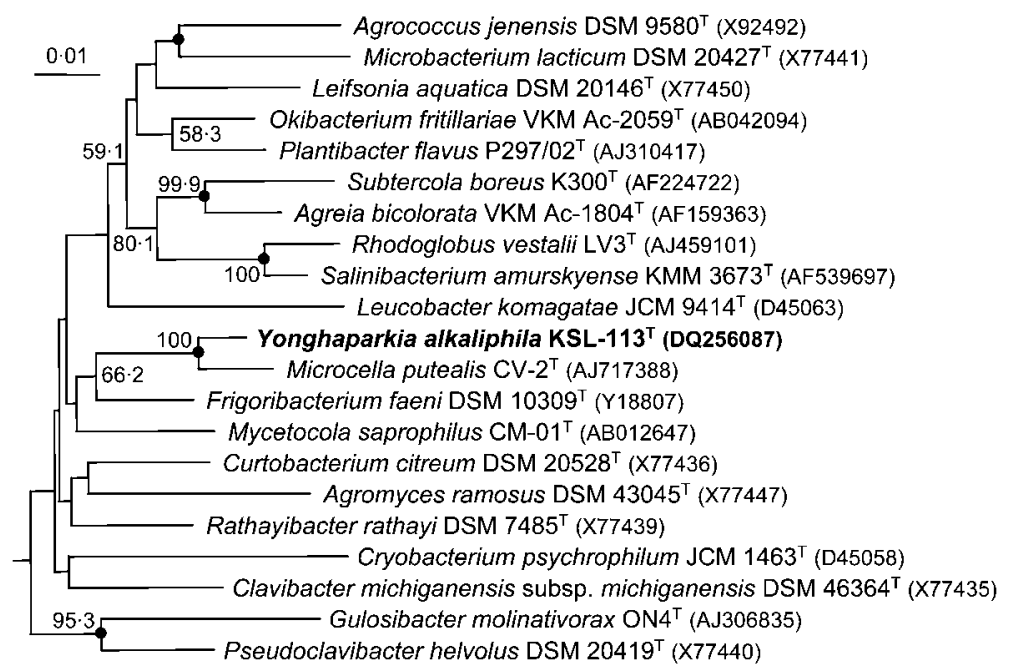

Fig. 1. Neighbour-joining phylogenetic tree, based on 16S rRNA gene sequences, showing the positions of strain $\mathrm{KSL}-113^{\top}$ and related taxa. Bootstrap values (from 1000 replications) are shown as percentages at each node; only values of $50 \%$ or more are shown. Dots indicate that the corresponding nodes were also recovered in trees generated with the maximum-likelihood and maximum-parsimony algorithms. Cellulomonas flavigena DSM $20109^{\top}$ was used as an outgroup (GenBank accession no. X83799; not shown). Bar, 0.01 substitutions per nucleotide position. 
and KSL-133 exhibited 16S rRNA gene sequence similarity values of $<96.0 \%$ (value for Rathayibacter rathayi DSM $7485^{\mathrm{T}}$ ) with respect to other members of the suborder Microbacteriaceae used in the phylogenetic analysis.

Cell-wall analysis showed that the peptidoglycans of strains KSL- $113^{\mathrm{T}}$ and KSL-133 contained 2,4-diaminobutyric acid $(\mathrm{DAB})$, alanine, glycine and glutamic acid in approximate ratios $1 \cdot 5: 0 \cdot 8: 1 \cdot 8: 1 \cdot 0$ and $1 \cdot 9: 0 \cdot 9: 1 \cdot 8: 1 \cdot 0$, respectively. The peptide Gly-D-Glu was present in partial peptidoglycan hydrolysates $\left(4 \mathrm{M} \mathrm{HCl} ; 45 \mathrm{~min}\right.$ at $\left.100^{\circ} \mathrm{C}\right)$ of both strains, indicating the presence of B-type cross-linkage. From these data, it was concluded that strains KSL-113 ${ }^{\mathrm{T}}$ and KSL-133 have the peptidoglycan type B $2 \gamma$, based on D-Glu-D-DAB, with Gly in position 1 and L-DAB in position 3, as described by Schleifer \& Kandler (1972). Strains KSL-113 ${ }^{\mathrm{T}}$ and KSL133 contained MK-12, at peak area ratios of approximately 61 and $70 \%$, respectively, as the predominant menaquinone; significant amounts (17-18\%) of MK-11 were also present. The major polar lipids detected in strains KSL-113 ${ }^{\mathrm{T}}$ and KSL-133 were diphosphatidylglycerol, phosphatidylglycerol, unidentified phospholipids and unidentified glycolipids. Strains KSL-113 ${ }^{\mathrm{T}}$ and KSL-133 had cellular fatty acid profiles that contained large amounts of branched fatty acids: the major components ( $>10 \%$ of total fatty acids) were anteiso- $\mathrm{C}_{15: 0}$, iso- $\mathrm{C}_{16: 0}$ and anteiso- $\mathrm{C}_{17: 0}$ (see Supplementary Table S1 available in IJSEM Online). The DNA G $+\mathrm{C}$ contents of strains KSL- $113^{\mathrm{T}}$ and KSL-133 were $71 \cdot 1$ and $71 \cdot 6 \mathrm{~mol} \%$, respectively.

Strains KSL- $113^{\mathrm{T}}$ and KSL-133 could be clearly distinguished from members of the family Microbacteriaceae by differences in chemotaxonomic properties. Strains KSL$113^{\mathrm{T}}$ and KSL-133 differed from the genera Microcella and Frigoribacterium, the closest phylogenetic neighbours, in terms of the predominant menaquinone type and the diamino acid in position 3 of the peptidoglycan. Members of the genera Microcella and Frigoribacterium contain MK-12 plus MK-13 and MK-9 as the predominant menaquinones, respectively, and possess D-lysine as the diamino acid in position 3 of the peptidoglycan (Kämpfer et al., 2000; Tiago et al., 2005). Strains KSL-113 $3^{\mathrm{T}}$ and KSL-133 were also distinguishable from the genus Microcella by differences in the cellular fatty acid profiles, particularly with regard to the major fatty acids (Tiago et al., 2005; Table 1 and Supplementary Table S1). Strains KSL- $113^{\mathrm{T}}$ and KSL-133 could be differentiated from other genera of the family Microbacteriaceae by differences in the predominant menaquinone and the diamino acid types (Kämpfer et al., 2000; Manaia et al., 2004; Lin et al., 2004). Although the chemotaxonomic properties of strains KSL- $113^{\mathrm{T}}$ and KSL133 were similar to those of members of the genus Agromyces, both strains exhibited a low level of $16 \mathrm{~S}$ rRNA gene sequence similarity with respect to the type species of the genus Agromyces (Fig. 1). When the DNAs of strains KSL- $113^{\mathrm{T}}$ and KSL-133 were used individually as labelled DNA probes for cross-hybridization, the mean DNA-DNA relatedness value was found to be $92 \%$, indicating that the two strains were members of the same genomic species (Wayne et al., 1987). In view of their combined phenotypic, phylogenetic and genetic similarities, strains KSL- $113^{\mathrm{T}}$ and KSL-133 can be considered as members of the same species. Therefore, on the basis of the data presented, strains KSL$113^{\mathrm{T}}$ and KSL-133 should be classified within a novel genus and species, for which the name Yonghaparkia alkaliphila gen. nov., sp. nov. is proposed.

\section{Description of Yonghaparkia gen. nov.}

Yonghaparkia (Yong.ha.park'i.a. N.L. fem. n. Yonghaparkia named after Yong-Ha Park, a Korean microbiologist who proposed the family Microbacteriaceae and has contributed significantly to bacterial systematics).

Cells are Gram-positive, non-spore-forming short rods or rods $(0 \cdot 2-0 \cdot 4 \times 0 \cdot 6-1 \cdot 4 \mu \mathrm{m})$. Strictly aerobic. The cell-wall peptidoglycan type is B2 $\gamma$ (based on D-Glu-D-DAB, with Gly in position 1 and L-DAB in position 3). The predominant menaquinone is MK-12; a significant amount of MK-11 is also present. The fatty acid profile consists of branched and straight-chain fatty acids. The DNA $\mathrm{G}+\mathrm{C}$ content is $71 \cdot 1-71.6 \mathrm{~mol} \%$ (HPLC). The type species is Yonghaparkia alkaliphila.

\section{Description of Yonghaparkia alkaliphila sp. nov.}

Yonghaparkia alkaliphila (al.ka.li.phi'la. N.L. n. alkali alkali; Gr. adj. philos loving; N.L. fem. adj. alkaliphila loving alkaline conditions).

Colonies are circular, slightly convex, smooth, glistening, yellow in colour and $1.5-2.0 \mathrm{~mm}$ in diameter after incubation for 10 days at $30^{\circ} \mathrm{C}$ on $2 \times$ diluted NA (pH 9.0). Growth occurs at 10 and $37^{\circ} \mathrm{C}$, but not at 4 or $38^{\circ} \mathrm{C}$. Optimal pH for growth is $9 \cdot 0$. Growth occurs in the absence of $\mathrm{NaCl}$ and in the presence of $2 \%(\mathrm{w} / \mathrm{v}) \mathrm{NaCl}$, but not in the presence of $3 \%(\mathrm{w} / \mathrm{v}) \mathrm{NaCl}$. Growth does not occur under anaerobic conditions on $2 \times$ diluted NA $(\mathrm{pH} \mathrm{9.0)}$ or on $2 \times$ diluted NA ( $\mathrm{pH} 9 \cdot 0)$ supplemented with nitrate. Urease-negative. Starch and Tween 40 are hydrolysed, but hypoxanthine, xanthine, L-tyrosine and Tweens 20, 60 and 80 are not. Negative for nitrate reduction. In assays with the API ZYM system, esterase (C4), esterase lipase (C8), leucine arylamidase, $\beta$-glucuronidase and $\alpha$ glucosidase are present, but alkaline phosphatase, lipase (C14), valine arylamidase, cystine arylamidase, trypsin, $\alpha$-chymotrypsin, acid phosphatase, naphthol-AS-BI-phosphohydrolase $\alpha$-galactosidase, $\beta$-galactosidase, $\beta$-glucosidase, $N$-acetyl- $\beta$-glucosaminidase, $\alpha$-mannosidase and $\alpha$-fucosidase are absent. Acetate, succinate, benzoate, Lmalate, formate and L-glutamate are not utilized as sole carbon and energy sources. Utilization of salicin is variable (positive for type strain). Susceptible to polymyxin B, streptomycin, chloramphenicol, gentamicin, novobiocin, lincomycin, oleandomycin, neomycin and carbenicillin, but not to penicillin G, ampicillin, tetracycline or kanamycin. The major fatty acids ( $>10 \%$ of total fatty acids) are 
anteiso- $\mathrm{C}_{15: 0}$, iso- $\mathrm{C}_{16: 0}$ and anteiso- $\mathrm{C}_{17: 0}$. The major polar lipids are diphosphatidylglycerol, phosphatidylglycerol, unidentified phospholipids and unidentified glycolipids. The DNA G + C content is $71 \cdot 1-71 \cdot 6 \mathrm{~mol} \%(71 \cdot 1 \mathrm{~mol} \%$ for type strain) (HPLC).

The type strain, KSL-113 ${ }^{\mathrm{T}} \quad\left(=\right.$ KCTC $19126^{\mathrm{T}}=\mathrm{CIP}$ $108920^{\mathrm{T}}$ ), was isolated from an alkaline soil from Korea.

\section{Acknowledgements}

This work was supported by the 21C Frontier program of Microbial Genomics and Applications (grant MG05-0401-2-0) and an NRL research program from the Ministry of Science and Technology (MOST) of the Republic of Korea.

\section{References}

Behrendt, U., Ulrich, A., Schumann, P., Naumann, D. \& Suzuki, K. (2002). Diversity of grass-associated Microbacteriaceae isolated from the phyllosphere and litter layer after mulching the sward; polyphasic characterization of Subtercola pratensis sp. nov., Curtobacterium herbarum sp. nov. and Plantibacter flavus gen. nov., sp. nov. Int J Syst Evol Microbiol 52, 1441-1454.

Cowan, S. T. \& Steel, K. J. (1965). Manual for the Identification of Medical Bacteria. London: Cambridge University Press.

Evtushenko, L. I., Dorofeeva, L. V., Subbotin, S. A., Cole, J. R. \& Tiedje, J. M. (2000). Leifsonia poae gen. nov., sp. nov., isolated from nematode galls on Poa annua, and reclassification of 'Corynebacterium aquatica' Leifson 1962 as Leifsonia aquatica (ex Leifson 1962) gen. nov., nom. rev., comb. nov. and Clavibacter xyli Davis et al. 1984 with two subspecies as Leifsonia xyli (Davis et al. 1984) gen. nov., comb. nov. Int J Syst Evol Microbiol 50, 371-380.

Evtushenko, L. I., Dorofeeva, L. V., Dobrovolskaya, T. G., Streshinskaya, G. M., Subbotin, S. A. \& Tiedje, J. M. (2001). Agreia bicolorata gen. nov., sp. nov., to accommodate actinobacteria isolated from narrow reed grass infected by the nematode Heteroanguina graminophila. Int J Syst Evol Microbiol 51, 2073-2079.

Evtushenko, L. I., Dorofeeva, L. V., Krausova, V. I., Gavrish, E. Y., Yashina, S. G. \& Takeuchi, M. (2002). Okibacterium fritillariae gen. nov., sp. nov., a novel genus of the family Microbacteriaceae. Int J Syst Evol Microbiol 52, 987-993.

Groth, I., Schumann, P., Weiss, N., Martin, K. \& Rainey, F. A. (1996). Agrococcus jenensis gen. nov., sp. nov., a new genus of actinomycetes with diaminobutyric acid in the cell wall. Int J Syst Bacteriol 46, 234-239.

Han, S. K., Nedashkovskaya, O. I., Mikhailov, V. V., Kim, S. B. \& Bae, K. S. (2003). Salinibacterium amurskyense gen. nov., sp. nov., a novel genus of the family Microbacteriaceae from the marine environment. Int J Syst Evol Microbiol 53, 2061-2066.

Kämpfer, P., Steiof, M. \& Dott, W. (1991). Microbiological characterization of a fuel-oil contaminated site including numerical identification of heterotrophic water and soil bacteria. Microb Ecol 21, 227-251.

Kämpfer, P., Rainey, F. A., Andersson, M. A., Lassila, E.-L. N., Ulrych, U., Busse, H.-J., Mikkola, R. \& Salkinoja-Salonen, M. (2000). Frigoribacterium faeni gen. nov., sp. nov., a novel psychrophilic genus of the family Microbacteriaceae. Int J Syst Evol Microbiol 50, 355-363.

Komagata, K. \& Suzuki, K. (1987). Lipid and cell wall analysis in bacterial systematics. Methods Microbiol 19, 161-207.
Lanyi, B. (1987). Classical and rapid identification methods for medically important bacteria. Methods Microbiol 19, 1-67.

Lin, Y.-C., Uemori, K., de Briel, D. A., Arunpairojana, V. \& Yokota, A. (2004). Zimmermannella helvola gen. nov., sp. nov., Zimmermannella alba sp. nov., Zimmermannella bifida sp. nov., Zimmermannella faecalis sp. nov. and Leucobacter albus sp. nov., novel members of the family Microbacteriaceae. Int J Syst Evol Microbiol 54, 1669-1676.

MacKenzie, S. L. (1987). Gas chromatographic analysis of amino acids as the $N$-heptafluorobutyryl isobutyl esters. J Assoc Off Anal Chem 70, 151-160.

Manaia, C. M., Nogales, B., Weiss, N. \& Nunes, O. C. (2004). Gulosibacter molinativorax gen. nov., sp. nov., a molinate-degrading bacterium, and classification of 'Brevibacterium helvolum' DSM 20419 as Pseudoclavibacter helvolus gen. nov., sp. nov. Int J Syst Evol Microbiol 54, 783-789.

Männistö, M. K., Schumann, P., Rainey, F. A., Kämpfer, P., Tsitko, I., Tiirola, M. A. \& Salkinoja-Salonen, M. S. (2000). Subtercola boreus gen. nov., sp. nov. and Subtercola frigoramans sp. nov., two new psychrophilic actinobacteria isolated from boreal groundwater. Int J Syst Evol Microbiol 50, 1731-1739.

Minnikin, D. E., O'Donnell, A. G., Goodfellow, M., Alderson, G., Athalye, M., Schaal, A. \& Parlett, J. H. (1984). An integrated procedure for the extraction of bacterial isoprenoid quinones and polar lipids. J Microbiol Methods 2, 233-241.

Park, Y.-H., Suzuki, K., Yim, D.-G. \& 7 other authors (1993). Suprageneric classification of peptidoglycan group B actinomycetes by nucleotide sequencing of $5 \mathrm{~S}$ ribosomal RNA. Antonie van Leeuwenhoek 64, 307-313.

Sasser, M. (1990). Identification of bacteria by gas chromatography of cellular fatty acids. Technical Note 101. Newark, DE: MIDI.

Schleifer, K. H. \& Kandler, O. (1972). Peptidoglycan types of bacterial cell walls and their taxonomic implications. Bacteriol Rev 36, 407-477.

Sheridan, P. P., Loveland-Curtze, J., Miteva, V. I. \& Brenchley, J. E. (2003). Rhodoglobus vestalii gen. nov., sp. nov., a novel psychrophilic organism isolated from an Antarctic Dry Valley lake. Int J Syst Evol Microbiol 53, 985-994.

Stackebrandt, E., Rainey, F. A. \& Ward-Rainey, N. L. (1997). Proposal for a new hierarchic classification system, Actinobacteria classis nov. Int J Syst Bacteriol 47, 479-491.

Suzuki, K., Sasaki, J., Uramoto, M., Nakase, T. \& Komagata, K. (1997). Cryobacterium psychrophilum gen. nov., sp. nov., nom. rev., comb. nov., an obligately psychrophilic actinomycete to accommodate "Curtobacterium psychrophilum" Inoue and Komagata 1976. Int J Syst Bacteriol 47, 474-478.

Takeuchi, M. \& Hatano, K. (1998). Union of the genera Microbacterium Orla-Jensen and Aureobacterium Collins et al. in a redefined genus Microbacterium. Int J Syst Bacteriol 48, 739-747.

Takeuchi, M., Weiss, N., Schumann, P. \& Yokota, A. (1996). Leucobacter komagatae gen. nov., sp. nov., a new aerobic grampositive, nonsporulating rod with 2,4-diaminobutyric acid in the cell wall. Int J Syst Bacteriol 46, 967-971.

Tamaoka, J. \& Komagata, K. (1984). Determination of DNA base composition by reverse-phase high-performance liquid chromatography. FEMS Microbiol Lett 25, 125-128.

Tiago, I., Pires, C., Mendes, V., Morais, P. V., da Costa, M. \& Veríssimo, A. (2005). Microcella putealis gen. nov., sp. nov., a Grampositive alkaliphilic bacterium isolated from a nonsaline alkaline groundwater. Syst Appl Microbiol 28, 479-487.

Tsukamoto, T., Takeuchi, M., Shida, O., Murata, H. \& Shirata, A. (2001). Proposal of Mycetocola gen. nov. in the family Microbacteriaceae and three new species, Mycetocola saprophilus sp. 
nov., Mycetocola tolaasinivorans sp. nov. and Mycetocola lacteus sp. nov., isolated from cultivated mushroom, Pleurotus ostreatus. Int J Syst Evol Microbiol 51, 937-944.

Wayne, L. G., Brenner, D. J., Colwell, R. R. \& 9 other authors (1987). International Committee on Systematic Bacteriology. Report of the ad hoc committee on reconciliation of approaches to bacterial systematics. Int J Syst Bacteriol 37, 463-464.

Yoon, J.-H., Kim, H., Kim, S.-B., Kim, H.-J., Kim, W. Y., Lee, S. T., Goodfellow, M. \& Park, Y.-H. (1996). Identification of Saccharomonospora strains by the use of genomic DNA fragments and rRNA gene probes. Int J Syst Bacteriol 46, 502-505.
Yoon, J.-H., Lee, S. T. \& Park, Y.-H. (1998). Inter- and intraspecific phylogenetic analysis of the genus Nocardioides and related taxa based on 16S rDNA gene sequences. Int J Syst Bacteriol 48, 187-194.

Yoon, J.-H., Kim, I.-G., Kang, K. H., Oh, T.-K. \& Park, Y.-H. (2004). Nocardioides aquiterrae sp. nov., isolated from groundwater in Korea. Int J Syst Evol Microbiol 54, 71-75.

Zgurskaya, H. I., Evtushenko, L. I., Akimov, V. N. \& Kalakoutskii, L. V. (1993). Rathayibacter gen. nov., including the species Rathayibacter rathayi comb. nov., Rathayibacter tritici comb. nov., Rathayibacter iranicus comb. nov., and six strains from annual grasses. Int J Syst Bacteriol 43, 143-149. 